\title{
Improving the Quality of Inpatient Services with Lean Service and Six Sigma Methods at Eshmun Hospital
}

\author{
Cristanto $^{1}$, Uni Pratama Pebrina Br Tarigan² \\ ${ }^{1,2}$ Universitas Prima Indonesia, Indonesia \\ unipratama@gmail.com
}

\begin{abstract}
Hospitals play an important role in the life of the nation and state, because every country has an obligation to meet all the physical and spiritual health needs of every citizen. The main focus of Eshmun Hospital is the accuracy of doctors in diagnosing diseases, responsive patient care, hospital security, hospital access roads, completeness of facilities, and medicines. The research method used in this research is six sigma, pareto diagram, failure mode effect analysis (FMEA), fishbone diagram, and value stream mapping. The conclusions obtained from this research are after repairs are made to the inpatient service activities of the hospital. Eshmun eats service activities which were originally 15 activities reduced to 11 activities, this can save time in carrying out services. Activities that are non-value add are very detrimental, including: the data collection service process is still done manually, patients are still waiting to receive treatment, there are some doctors who are not professional. The main cause of waste is usually caused by hospitals not keeping up with the times, human resources that are not optimal.
\end{abstract}

\section{Keywords}

service; health;

eshmun hospital

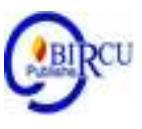

\section{Introduction}

The problem of public services is one of the most complicated problems in Indonesia, many people do not believe in the government's ability to provide adequate public services. This is indicated by the fact that there are people who make various kinds of complaints such as the performance of public care is less effective, lack of adequate information, and the difficulty of the community to reach these services. More (2020) stated that one way to achieve the effectiveness of a company is to foster and utilize human resources in order to produce a quality workforce, physically and mentally healthy, and have high skills to support the company's success.

The health sector is no exception, although nowadays we have been given various kinds of advances in technology, the government is considered to be lacking in providing equitable health services, so that people feel that the government is indifferent to the health of its citizens. To support this, the government must provide good health services. Customer satisfaction is the main goal of a service performed. Satisfactory health services can be seen from the general public's view of a health institution working optimally or not. To realize health services, the government builds hospitals, health centers, etc. Hospitals play an important role in the life of the nation and state, because every country has an obligation to meet all the physical and spiritual health needs of every citizen. To support this, hospitals are required to provide the best possible service to every community in need of treatment, besides they have to keep competing against other competitors, hospitals are forced to follow the standards set by other hospitals. 
Measurement of patient satisfaction is carried out by hospitals on a regular basis, because nowadays people are increasingly focused on the health of each individual. This is done to measure the extent to which the quality of hospital services that have been provided. The results of these measurements can be used as an illustration of the quality that needs to be improved in the future.

The main focus of Eshmun Hospital is the accuracy of doctors in diagnosing diseases, responsive patient care, hospital security, hospital access roads, completeness of facilities, and medicines. The new hospital should pay more attention to the quality of hospital services, including Eshmun Hospital. This is because the location is quite close to the old hospital and there is no review on patient satisfaction that can be used as a reference for service management at Eshmun Hospital. The Eshmun Hospital visit report shows that in January-May there was a drastic increase in visits but from June to the end of the year there was a decrease. Even though in the provision of services, the Eshmun Hospital has tried to work optimally, but there are still people who give criticism.

Based on the above background, the problem discussed is the service that is not optimal at Eshmun Hospital. The occurrence of waste in activities resulted in the service not running optimally and efficiently. So waste analysis and improvement in service is needed.

The objectives of this research are:

1. Identify wasteful activities that occur in Eshmun Hospital.

2. Making improvements and optimizing time at Eshmun Hospital.

3. Improving the quality of service at Eshmun Hospital.

The expected benefits of this research are:

1. For Organizations (Hospitals)

Through this research the hospital will be helped to optimize the quality of hospital services.

2. For University

Provide references for further research. And become an active academic forum to improve Indonesian academics and solve community issues.

3. For Students

Students gain new knowledge and can be applied to the organization studied.

\section{Review of Literature}

\subsection{Hospital}

Hospitals are one of the drivers of the life of a country, therefore hospitals must provide a variety of maximum and adequate services. The services provided must be the best and easily accessible by the community regardless of the caste of the community. The community has the same rights in getting the services of a hospital. Patient safety is the most important thing (priority) for a hospital. According to Mulyanti (2020) The real rate or tariff for hospital services is the value of a service which is determined by the size of an amount of money based on the consideration that with this money value a hospital is willing to provide services to patients.

\subsection{Brainstorming}

Brainstorming is a way that is done so that every member of an institution or group can provide ideas/thoughts that are systematic and patterned. Brainstorming plays an important role in the emergence of various creative ideas and then formed into something clearer. Brainstorming encourages an individual to think freely without fear of criticism from others (Mollah et al., 2018). 


\subsection{Service}

Service has a meaning, namely a sacrifice made by someone to achieve the needs of others. The services provided must be carried out properly and in detail so that customers are satisfied with the services that have been obtained. The forms of service are: oral, written, and deed services (Panjaitan and Yulianti, 2016). According to (Sulastiyono, 2002:41) service is an effort made by someone to meet the needs of others, can be in the form of physical, social and psychological needs.

\subsection{Lean Service}

Lean Service is a concept that focuses on identifying and eliminating a waste activity that often occurs in a production activity. Lean also focuses on continuous quality improvement so that a production activity can be free from waste so that it can run regularly and effectively. If this process is not carried out, a company can lose the trust of its customers, resulting in a lack of profits in a company. According to Gaspersz (2008) the concept of lean service is a concept that encourages a business to continue to make continuous improvements in addition to reducing and eliminating activities that are considered wasteful with the aim of achieving customer satisfaction.

The APICS Dictionary defines lean as a business philosophy that based on the minimization of the use of resources (including time) in various company activities. Lean's focus is on identification and elimination of non-value added activities activities) in design, production for manufacturing or operations for services sector, and supply chain management, which are directly related with customers. Where are the activities that do not add value? In other terms called non-value-adding-activities.

There are five basic lean principles, namely:

1. Identify the value of the product (goods and or services) based on customer perspective, where customers always want the product of superior quality, at competitive prices, and with timely delivery.

2. Identify the value stream process mapping or process mapping in the value stream for each product or service.

3. Eliminate non-value-added waste from the whole activities throughout the value stream process.

4. Organize so that materials, information, and products flow smoothly smoothly and efficiently throughout the value stream process using the system pull (pull system).

5. Constantly looking for improvement techniques and tools (improvement tools and techniques) to achieve excellence and continuous improvement.

Gasperz (2008) states that Lean service has five basic principles, namely:

1. The exact specification of the product value desired by the customer.

2. Identify the value stream for each service process.

3. Eliminate all waste in the service process flow (moment of truth) so that the value flows without a hitch.

4. Establish an anti-error system (mistake-proof system) for each service process to avoid wastage and delay.

5. Striving for excellence to achieve perfection (zero-waste) through continuous improvement. 


\section{Research Methods}

The object of this research itself is quite broad so that the problem limits are needed, as for the problem limitations in this study, namely:

1. This study was conducted on outpatient services at Eshmun Hospital.

2. This research is limited to serving patients at Eshmun Hospital from entering the registration room to completion.

3. This study discusses wasteful activities that occur during service at Eshmun Hospital.

The assumptions that form the basis of this research are:

1. RS. Eshmun performs services normally.

2. RS. Eshmun improves the quality of outpatient services well.

The research method used in this research is six sigma, pareto diagram, failure mode effect analysis (FMEA), fishbone diagram, and value stream mapping. Six sigma is a method used to determine whether the quality of the product produced is good or not. If the sigma value of a company's production process, the possibility of a product defect is getting smaller and vice versa. This method has the aim of producing the maximum possible process that leads to customer satisfaction. In an effort to achieve this, optimal contributions from various parties concerned must be required so that the compiled process can run smoothly and optimally (Wilujeng and Wijaya, 2019).

Pareto diagrams play an important role in determining which priority problems will be solved. Pareto diagrams make it easier to determine the largest to smallest problems so that they can determine the most appropriate steps to be taken. Pareto charts can be drawn in the form of a bar, the higher the bar graph, the more often the problem occurs and vice versa (Zuniawan et al., 2020). Failure mode effect analysis (FMEA) is a method used to determine what effects will occur in a production activity. In other words, this method/method analyzes the problems that will arise in a production activity that will be carried out, then preventive measures are taken against the most likely problems that have been analyzed before hand (Hisprastin and Musfiroh, 2020). Fishbone diagrams are often referred to as fishbone diagrams. This diagram aims to find out the root causes of a problem and then spark ideas for solving the problem. Fishbone diagrams describe which problems need to be solved immediately and provide ways to solve these problems (Tan, 2012).

Value stream mapping is a quality management tool that makes continuous improvement and reduces waste. This concept is derived from the lean concept. Value stream mapping examines the added value of each step in a production wheel. VSM also emphasizes various value-added activities. Value stream is described as all activities and information that provide added value and do not add value to the product/service for all business processes such as design concept to manufacture or produce raw materials/materials into products requested by customers. Value stream mapping is a visual description of the product/service such as value-added and non-value-added activity information in generating products/services. Value stream mapping can be used to describe and analyze current status for product flow and design future status focused on waste reduction, lead time improvement, and work flows. There are two types of value stream mapping, namely the current state map and the future state map folder. The current state map is a configuration of the current product/service value stream and using special icons. Initial stages in making the current state map is to make a mapping of material flows and related information with material flow to provide an actual picture of the process production and identify wastes that occur in the flow materials that occur on the production floor. While the future state map acts as a blueprint for lean change to the desired state. 
design future state map is done to reduce the waste that occurs. For carry out continuous improvement, it is necessary to do process mapping what's happening now to find improvements that can be made. According to Nash et al. (2008) VSM is a method used to describe the flow of materials from basic materials to products that are economical. The purpose of value stream mapping is to identify all types of waste activities and take steps to minimize waste. The step is to improve the entire process flow, not just in pieces.

\section{Results and Discussion}

\subsection{Define}

At this stage, research is conducted on consumers who are involved in the process of health services at Eshmun Hospital. Therefore, a questionnaire for hospital services is needed, which is the stage of identifying the source of patient dissatisfaction. In this study, it was identified what activities took place during health services at Eshmun Hospital and then used lean tools to optimize service activities at Eshmun Hospital.

\subsection{Measure}

At this stage the measurement of the ability of the health service process in the hospital is carried out Eshmun Hospital. Observations were made by identifying which activities were wasteful and did not add value to the patient.

Wasteful activities that often occur in this hospital are:

\section{Waiting Activity}

Where the patient waits too long because there are doctors who have not arrived when the patient arrives. This activity greatly hampers the service process at the hospital. It is hoped that things like this can be reduced again so that the service process can be carried out effectively.

2. The habit of nurses who take files that are not important, walk to another place just to pass the initial place they passed. Usually, a medical track record form is submitted to the receptionist.

3. The nurse re-enters the patient's personal data, even though the patient's data has been recorded in the patient's track record at the hospital, especially when the patient forgets to bring the patient card that has been given by the hospital.

Table 1. VA and NVA Activities

\begin{tabular}{|l|l|c|c|}
\hline No. & Activity & Service Time (Second) & Description \\
\hline 1 & Patient fills in registration form & 360 & NNVA \\
\hline 2 & $\begin{array}{l}\text { The administration section } \\
\text { performs data collection manually }\end{array}$ & 615 & NVA \\
\hline 3 & $\begin{array}{l}\text { Delivery of medical records to the } \\
\text { examination room }\end{array}$ & 212.5 & NNVA \\
\hline 4 & Check done & 50.6 & VA \\
\hline 5 & Administration is back in its place & 145.8 & NNVA \\
\hline 6 & Patient takes queue number & 68.7 & NVA \\
\hline 7 & Patient waiting for call & 925.6 & NNVA \\
\hline 8 & $\begin{array}{l}\text { The patient goes to the } \\
\text { examination room }\end{array}$ & 450.4 & NVA \\
\hline 9 & Patient waiting for doctor & 1600.6 & VA \\
\hline 10 & $\begin{array}{l}\text { The patient tells various symptoms } \\
\text { to the doctor }\end{array}$ & 500.7 & \\
\hline
\end{tabular}




\begin{tabular}{|c|l|c|c|}
\hline 11 & Patient receiving doctor's care & 700.6 & VA \\
\hline 12 & Doctor picks up equipment & 5.9 & NNVA \\
\hline 13 & Doctor diagnoses patient's disease & 56.7 & VA \\
\hline 14 & Doctor gives prescription & 120.7 & VA \\
\hline 15 & Patient returns to administration & 653.8 & NNVA \\
\hline 16 & File completion & 180.7 & VA \\
\hline 17 & $\begin{array}{l}\text { Patient goes to the nearest } \\
\text { pharmacyotik }\end{array}$ & 300 & NNVA \\
\hline 18 & Officers check drug availability & 550 & VA \\
\hline 19 & Officer giving medicine & 90 & \\
\hline
\end{tabular}

From the table above, it can be seen that the service activities of Eshmun Hospital are still a lot of wasteful activities, through research it can be seen that the NVA value in Eshmun Hospital is worth: 5638.3, while the VA is only worth: 2000. This means that almost half of the activities in the hospital is a wasteful activity. For this reason, the process of identifying service activities is carried out so that service activities are fast and free from waste.

\subsection{Analyze}

At this stage the identification of the factors causing a waste activity, usually using a fish diagram (fishbone diagram). Here the intended activity is repetitive and less important activity, patients still ask questions even though there are already available instructions, lack of coordination between nurses and doctors on duty (miscommunication), patients are usually forced to wait more than usual time.

\subsection{Improve}

At this stage the researcher proposes an improvement design, by removing every activity that is included in wasting activities. In the process this activity reduces wastage time so that service can take place quickly. Some of the actions that can be taken for the process of improving inpatient services at this hospital are:

1. Improving the ability of nurses to serve a patient.

2. Regular drug stock recording every week.

3. Improving the standard operating procedure (SOP) once a year as an evaluation of the service level of Eshmun Hospital.

4. Keeping up with technological developments so that the treatment process can be carried out more quickly and effectively.

5. Provide excellent service training to various hospital health units.

6. Control

This is the stage where supervision is carried out on the improvements made. The flow of the production process must be free from wasteful actions. In other words, in this process every process that has been improved and optimized, then the process will be used for a long time and reduce problems in the future. 


\section{Conclusion}

The conclusions obtained from this research are:

1. After repairs are made to the inpatient service activities of the hospital. Eshmun eats service activities which were originally 15 activities reduced to 11 activities, this can save time in carrying out services.

2. Activities that are non-value add are very detrimental, including: the data collection service process is still done manually, patients are still waiting to receive treatment, there are some doctors who are not professional.

3. The main cause of waste is usually caused by hospitals not keeping up with the times, human resources that are not optimal.

The following are some suggestions that the relevant parties may consider:

1. Through this research, if the related parties can find out what things can hinder the service process at Eshmun Hospital, then the hospital can implement it in daily life.

2. It is hoped that further research from various masters of knowledge will assess the quality of patient care at the hospital.

\section{References}

Hisprastin, Yasarah \& Ida Musfiroh. (2020). Ishikawa Diagram dan FMEA sebagai Metode yang Sering Digunakan dalam Manajemen Resiko Mutu di Industry. Bandung: Universitas Padjajaran.

Gaspersz, Vincent. (2008). Lean Six Sigma for Manufacturing and Services Industries. Jakarta: PT Gramedia Pustaka Utama.

Mollah, Mochammad Kalam, Misbahul Munir, \& Anis Wulan Sari. (2018). Peningkatan Kualitas Pelayanan dengan Metode Pendekatan Lean Service di Perusahaan Jasa Transportasi. Surabaya: Institut Teknologi Adhi Tama.

Mora, Z. (2020). Effect of Work Safety and Work Healthy Towards Employee's Productivity in PT. Sisirau Aceh Tamiang. Budapest International Research and Critics Institute-Journal (BIRCI-Journal), p. 753-760.

Mulyanti, et al. (2020). Comparison Analysis of Real Costs with Ina-CBG Rate's Ischemic Stroke Disease in Installations in Regional Public Hospitals X in Banda Aceh 2019. Budapest International Research and Critics Institute-Journal (BIRCI-Journal). P. 2479-2493.

Nash, Mark A. \& Poling, Sheila. (2008). Mapping the Total Value Stream. New York: A Productivity Press Book.

Panjaitan, Januar Efendi \& Ai Lili Yulianti. (2016). Pengaruh Kualitas Pelayanan terhadap kepuasan pelanggan pada JNE Cabang Bandung. Bandung: Universitas Telkom.

Sulastiyono, Agus. (2002). Manajemen Penyelenggaraan Hotel. Edisi Pertama, Bandung: Penerbit CV Alfabeta.

Tan, Hendy Tannady. (2012). Metode DMAIC sebagai Solusi Pengendalian Kualitas Produksi Sepatu Tambang. Jakarta: Universitas Bina Nusantara.

Wilujeng, Fuji Rahayu \& Tony Wijaya. (2019). Penerapan Metode DMAIC untuk Pengendalian Kualitas pada UKM Tempe Semanan. Jakarta: Universitas Trisakti.

Zuniawan, Akhyar Yohanes Suryono, \& Octoberry Julianto. (2020). Implementasi VSM pada Manufaktur Belt Conveyor Part untuk Mengurangi Cycle Time. Jakarta: Universitas Mercu Buana Jakarta. 